\title{
New breeding sites of the critically endangered northern bald ibis geronticus eremita on the moroccan atlantic coast
}

\begin{abstract}
The Northern Bald ibis Geronticus eremita, is globally listed as a critically endangered bird species. The last surviving world population that occurs in the wild is mainly confined to the southwest of Morocco. The known breeding sites are almost restricted to the Souss-Massa National Park and Tamri area on the Morocco's Atlantic costal band south and north to Agadir city. During the 2017 reproductive season, we discovered two new breeding sites with at least three confirmed active nests incubated by adults at two distinct coastal cliffs. In addition, a flock of 11 to 15 ibises was located, at the northern coastline edges of the known breeding range in southwest Morocco. The new breeding sites of Northern Bald ibis described here suggest a current extension of the breeding range of this relict species along the Moroccan Atlantic coastline.
\end{abstract}

Keywords: nesting sites, northern bald ibis, geronticus eremite, atlantic coast, morocco
Volume 2 Issue 3 - 2017

\author{
Mohamed Aourir,' Halima Bousadik, ${ }^{2}$ \\ Mohamed El Bekkay, ${ }^{3}$ Widade Oubrou, ${ }^{3}$ \\ Mohamed Znari, ${ }^{4}$ Abdeljebbar Qninba ${ }^{5}$ \\ 'Department of Biology, Ibn Zohr University, Morocco \\ ${ }^{2}$ GREPOM-Birdlife Maroc, Residence Oum Hani n ${ }^{\circ}$ 3, Morocco \\ ${ }^{3}$ Souss-Massa National Park, High Commissariat for Water and \\ Forests and Desertification, Morocco \\ ${ }^{4}$ Department of Biology, Cadi Ayyad University, Morocco \\ ${ }^{5}$ Department of Animal Biology and Physiology, Institut \\ Scientifique, MohammedV University, Morocco
}

Correspondence: Mohamed Aourir, Department of Biology, Faculty of Science, Ibn Zohr University, Agadir, Morocco, Email maourir@gmail.com

Received: July 27, 2017 | Published: August 08, 2017

\section{Introduction}

The Northern Bald Ibis Geronticus eremita (Linnaeus, 1758), a cliff-nesting and one of the world's most threatened species, has been classified as Critically Endangered (C2a (ii) version 3.1) since 1994. ${ }^{1}$ The species historic distribution range indicates that it was widespread in central Europe, Middle East, and North Africa. Since the beginning of the $20^{\text {th }}$ century, the last known remnant wild birds had been restricted to the populations of North-western Africa (Morocco and Algeria) and the Middle East (Syria and Turkey).,.3 These very big distribution range shrinking and severe population decline were due to a combination of various factors such as habitat loss, direct persecution and disturbance and probably also the effects of climate change. ${ }^{2,4}$

Accordingly, it was reported that the species declined by $98 \%$ between 1900 and 2002, mainly due to destruction of its habitats, human disturbance, and long-term global fluctuations in rainfall and the use of pesticides. ${ }^{5,6,2}$ The survivors of the colony of Birecik, southern Anatolia, Turkey, had been prevented from migrating and became rather semi-captive. ${ }^{7}$ By contrast, the last remaining colony seems to be extinct in the late 1980s in Algeria. ${ }^{8}$ Recently, a relict colony of seven individuals was rediscovered in 2002 in Syria., ${ }^{9}, 10$ Unfortunately, this sub colony has probably gone extinct as a small and probably non-viable population. ${ }^{1}$

Since 2008, the reintroduced Northern Bald ibis in southern Spain has bred every spring, with a slow increase in numbers. In the context of a project evaluating the efficacy of different controlled release methods, 257 birds were released from 2004 to $2011 .^{11}$ Several ringed ibises from Spain were then observed in northern Morocco after crossing the Strait of Gibraltar. Two ringed birds were seen in Morocco (in Middle Atlas and Merja Bargha), in 2005 and
2007, respectively. ${ }^{11}$ More recently, six ibises reaching the Moroccan northern coast crossing from Spain were observed in 2016. ${ }^{12}$ These observations suggest that the reintroduced ibises are expanding their home range southwards.

However, the remaining wild Northern Bald ibis population is still confined to two main sites on the Atlantic coastline of Morocco, namely the Souss-Massa National Park (SMNP, south to Agadir) and Tamri (around $50 \mathrm{~km}$ north to Agadir), where the species is largely resident (Figure 1). ${ }^{13}$ The species remains very vulnerable to any one-off disasters due to the social behaviour complexity of the species, which breeds colonially and usually feeds in groups, and to the reduced population size. ${ }^{14}$ The SMNP has been created in 1991 to protect these remnant ibis colonies. Since 1994, the nesting colonies have been subject to a long-term study in two known nesting sites in the abovementioned area: three subcolonies were located on a very small zone within the SMNP, over a surface area of c. 38000 ha; and another colony that includes the half of the breeding population, is located nearby Tamri (Figure 1). As a consequence of successful protection efforts by the authorities of the SMNP, the Royal Society for the Protection of Birds (RSPB), BirdLife International and its Spanish partner (SEO), the total population size in the SMNP and Tamri reached 601 birds at the end of the 2016 breeding season including 111 breeding pairs. ${ }^{15}$ This gradual improvement in the status of this relict population provides a possibility for a natural extension of the breeding range to other sites within and out of the Souss-Massa area (SMNP and Tamri colonies), particularly along the Atlantic coastline where suitable breeding cliffy habitats have not been surveyed yet.

In the present study, we reported and described two newly colonized nesting cliffs and nests on the Moroccan Atlantic coastline, north to the already known colonies (SMNP and Tamri). 


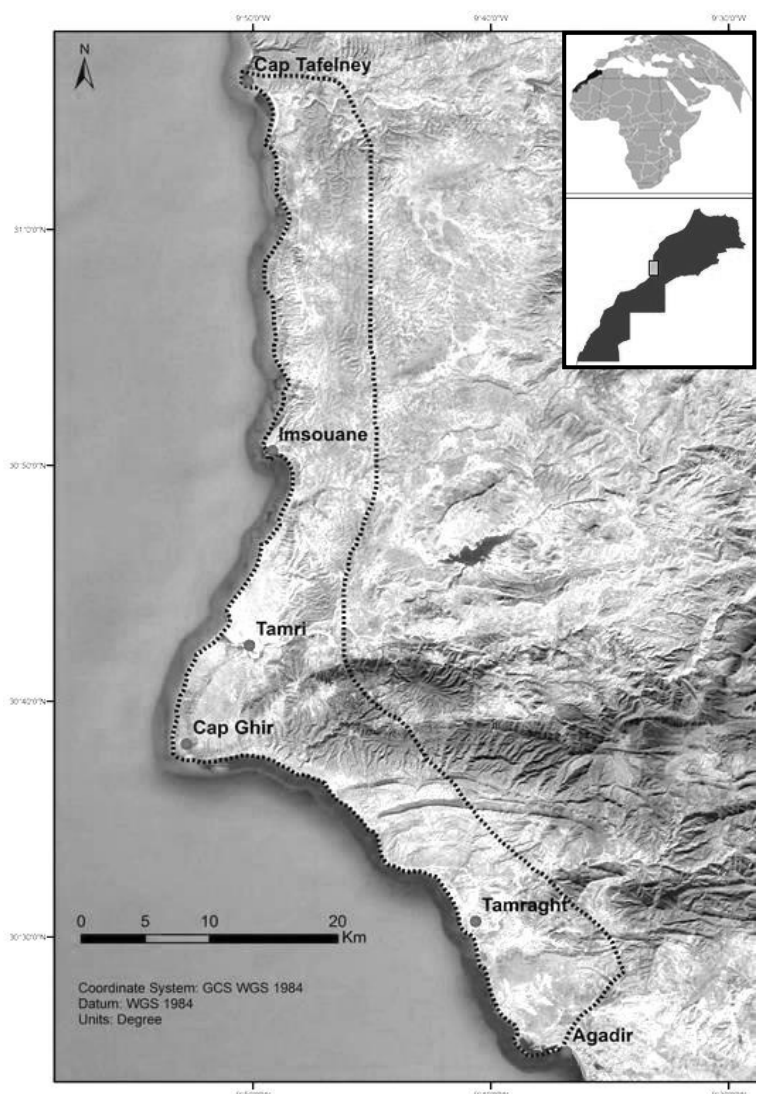

Figure I Relative locations of new nesting sites and surveys for the Northern Bald ibis in Morocco's south-west Atlantic coastline.

\section{Material and methods}

A two-stage methodology was adopted in order to facilitate field prospections for potential breeding and nesting sites on the Moroccan Atlantic coastline, which extends from Imsouane $\left(30^{\circ} 50^{\prime} 38^{\prime \prime} \mathrm{N}\right.$; $9^{\circ} 49^{\prime} 26^{\prime \prime} \mathrm{W}$ ), around $85 \mathrm{~km}$ north to Agadir, to Cap Tafelney $\left(31^{\circ} 06^{\prime} 10^{\prime \prime} \mathrm{N} ; 9^{\circ} 50^{\prime} 02^{\prime \prime} \mathrm{W}\right)$, at $70 \mathrm{~km}$ south to Essaouira (Figure 1). First, we used Google earth images to identify five key cliffs and potential nest sections of the study area. The shoreline, length of approximately $25 \mathrm{~km}$ is characterized by live cliffs, which are made up of alternate beds of aeolianite (consolidated sand dunes), marls, and limestone, which give different sections vertical in parts only and separated locally by narrow sandy beaches. A band of coastal steppe of $1-2 \mathrm{~km}$ width, between the coast and the foothills of the High Atlas Mountains, is globally unintensively used.

Secondary breeding habitats and active nests were surveyed by walking through each suitable coastline, from mid-March to late April 2017. The observer inspected all ledges and cavities using binoculars. At each suitable cliff, we localised the places where ibises occur or where (a) pair (s) initiated (a) nest (s), or the existence of active nests (incubating birds), and occupied roosting sites. We systematically search for foraging ibises throughout the steppe band within the study area. Each nest located was then inspected every 5 to 7 days, from $28^{\text {th }}$ March to late June 2017, using binoculars. Moreover, information on sightings and movements of the ibises were collected while interviewing local population that was familiarized with these birds, especially fishermen, shepherds and trekking guides, using photorecognition.

\section{Results and discussion}

On $28^{\text {th }}$ March 2017, we discovered a first new breeding site (Cliff 1) on the coastal cliffs north to Imsouane, at about $30 \mathrm{~km}$ north of the previously known colony of Tamri (Figure 1). We recorded two nests with incubating adult birds and one pair displaying copulation behaviour. These three breeding pairs, associated with several Rock doves Columba livia (4 to 6 breeding pairs), were established on a westerly sea-oriented straight Cliff at c.10-12 m a.s.l. Both nests were constructed on the small roofs with an overhanging black rock providing cover from sunshine all day long.

On $8^{\text {th }}$ April, another nesting site (Cliff 2) with an active nest and an apparently non-nesting pair (nest not located) were detected, among a 24-breeding pairs colony of the Moroccan Great Cormorant Phalacrocorax carbo maroccanus and a breeding colony of Plain swift Apus unicolor, between Imsouane and Tillit, at about $32 \mathrm{~km}$ north of Tamri's colony (Figure 1). This active nest, with an incubating adult and the other parent standing on a ledge nearby the nest, was located in a small natural hole in the limestone wall of a westerly-oriented and sun-exposed high cliff; at c.20-25m a.b.1.

In order to protect these new nesting sites, their precise locations are not provided here. On the same day, we observed 11 to 15 Northern Bald ibises together in a roosting site at the top of a cliff located few kilometres further north, not far away from cap Tafelney. Subsequently, we intensified nest-searching effort along the coastline section between Cap Tafelney and Tillit localities from $8^{\text {th }}$ to late April 2017. However, we did not locate any active nest despite the intense prospection effort carried out in this area. On the other hand, and according to the local people that we interviewed, the species seems to have recently appeared in the area. Northern Bald Ibises has been regularly observed, foraging in an undulating and narrow coastal steppe, or roosting on costal Cliffs between Cap Tafelney and Imsouane localities since three years ago.

At least, three confirmed active nests with incubating adults and two pairs with breeding attempts (ibises displayed meeting behaviours) but no nesting were recorded at two distinct coastal Cliffs, at about 85 and $32 \mathrm{~km}$ north to the previously known colonies of SMNP and Tamri, respectively. In addition, we observed a flock of 11 to 15 ibises sporadically roosting, sun bathing or foraging in the coastline area between Cap Tafelney and Tillit. This suggests that a new subcolony is likely to be established in this area.

The monitoring of the three active nests was pursued, by weekly inspection, until the fate of each nest was known (Table 1). At Cliff 1 , the nest $n^{\circ} 1$ failed, probably before egg laying as it was destroyed due to an unknown cause. In the second active nest (nest $n^{\circ} 2$, Cliff 1 ), three eggs were produced and continuously incubated. On $2^{\text {th }}$ April, one egg was observed outside the nest and two chicks hatched during the period between $21^{\text {st }}$ and $25^{\text {th }}$ April 2017. Shortly after hatching, a chick disappeared, probably fell into the sea or predated by Yellowlegged Gulls Larus michahellis, usually seen roosting at the top of the cliff 1 . The second chick was killed a week after hatching because of an entanglement by a monofilament fishing line at the nest; its decaying carcass was observed suspended on $3^{\text {th }}$ May 2017.

At Cliff 2, one active nest was established, probably during lateMars, because adults were still bringing nest materials when the nest was recovered. The number of eggs and chicks at their earlier stages of development could not be recorded accurately inside the nest (small natural hole in the limestone wall), but two chicks were raised at the nest on $24^{\text {th }}$ May 2017 and only one juvenile flight from the nest. 
Therefore, the breeding success (mean fledged young per nesting pair) was only 0.5 .

After a marked decline in 1997, the prebreeding size and reproductive success of the two known colonies (SMNP and Tamri) of the Northern Bald ibis, exhibited significant changes over the past two decades. The doubling of the number of nesting pairs that laid eggs, from 77 pairs $(1996)^{14}$ to 111 pairs $(2016),{ }^{15}$ should be followed by an expansion of the breeding sites at the northern edges of the known breeding range in southwest Morocco. The lack of suitable nesting sites between Tamri and Cap Ghir, $37 \mathrm{~km}$ northwest to Agadir may explain the trend of northward expansion. Such an expansion suggests at least two possible hypotheses: first, the sporadic breeding of North Bald ibises at the range limits always exists, but prospecting in previous years has not been rigorous enough, so that sites with small numbers of birds were unnoticed in previous years. Second hypothesis, the population size has risen recently, and northward breeding range expansion has followed as consequence of saturation of the previously known sites, especially in the colony of Tamri. This last hypothesis can be supported by the high number of non-nesting pairs comparatively to the nesting one $(60 \mathrm{vs} .53$ pairs, respectively during 2016 breeding season ${ }^{15}$ at the colony of Tamri.

Table I Summarized data on breeding in Northern Bald Ibis in the Moroccan Atlantic coastline

\begin{tabular}{|c|c|c|c|c|c|c|}
\hline $\begin{array}{l}\text { Nesting } \\
\text { site }\end{array}$ & $\begin{array}{l}\text { Pair } \\
\text { number }\end{array}$ & Behaviour & $\begin{array}{l}\text { Clutch } \\
\text { size }\end{array}$ & $\begin{array}{l}\text { Hatching } \\
\text { date }\end{array}$ & $\begin{array}{l}\text { Chicks seen in } \\
\text { the nest }\end{array}$ & $\begin{array}{l}\text { Chicks flight from the } \\
\text { nest }\end{array}$ \\
\hline \multirow{3}{*}{ Cliff I } & I & $\begin{array}{l}\text { Nesting and Nest } \\
\text { building }\end{array}$ & Unknown & $\begin{array}{l}\text { Failed } \\
\text { Nest destroyed }\end{array}$ & & \\
\hline & 2 & Nesting & 3 eggs & $21-25^{\text {th }}$ April & $\begin{array}{l}2 \text { chicks } \\
\text { I chick disappeared } \\
\text { I chick killed }\end{array}$ & \\
\hline & 3 & Courtship and copt & no-nesting & & & \\
\hline \multirow{2}{*}{ Cliff 2} & I & Nesting & Unknown & Unknown & 2 chicks, on $24^{\text {th }}$ May & $\mathrm{I}$ juvenile, on $3 \mathrm{I}^{\text {th }}$ June \\
\hline & 2 & Mating / no-nesting & & & & \\
\hline
\end{tabular}

Breeding cliffs characteristics are relatively well investigated for the Northern Bald ibis in Morocco. ${ }^{16,17}$ At the current breeding colonies in the SMNP, the Northern Bald ibis seems to prefer ledges and platforms as nest sites on vertical or subvertical cliffs. The existence of suitable ledges on cliff sections depends greatly on the lithological and erosional characteristics of the cliffs. The position and form of such ledges, the sun-exposure, and dimensions of the ledges have important considerations in the suitability of a potential nesting site. ${ }^{17}$ The newly nesting cliffs used seem very similar to that used on the sea cliffs occupied by breeding birds in other Moroccan colonies of the SMNP. Rocky hole (nest $n^{\circ} 1$, cliff 2 ) showed higher breeding success compared to the ledges with overhangs used at the Cliff 1 , which is least favoured. Such "cavity" nest locations gave protection from predators in the former Middle Atlas colonies of Morocco. ${ }^{16}$ The entanglement of chicks at the nest by monofilament fishing lines perhaps affects the productivity of Northern Bald ibis in its breeding range in the southwest Moroccan Atlantic cost. Educating fishermen about the hazards posed by lost and discarded fishing debris, and including removal of fishing lines and debris around nesting sites, should be considered as part of a very important action of the conservation.

\section{Conclusion}

Our observations provide evidence for an extension trend of the breeding range of Northern Bald ibis, northwards of its known breeding range in southern Morocco. It is clear that inventorying of Northern Bald ibis colonies in southwest Morocco has not been fully completed, and there is still a need to investigate movements of the birds as some small colonies might still be found in the few areas not surveyed. Moreover, knowing the reasons of the presence of the ibises in newly discovered sites may be important to address conservation measurements.

\section{Acknowledgements}

None.

\section{Conflict of interest}

The author declares no conflict of interest.

\section{References}

1. UICN. The IUCN Red list of threatened species. 2016.

2. Collar NJ, Stuart SN. Threatened birds of Africa and related islands: the ICBP/IUCN Red Data Book. Cambridge, UK; 1985.

3. Pegoraro K, Föger M, Parson W. First evidence of DNA sequence differences between Northern Bald ibises (Geronticus eremita) of Moroccan and Turkish origin. Journal für Ornithologie. 2001;142(4):425-428.

4. Hirsch U. Northern Bald ibis. Study West Palearctic Birds. 1979;72:313325 .

5. Safriel UN. Notes on the extinct population of the northern bald ibis (Geronticus eremita) in the Syrian Desert. Ibis. 1980;122(1):82-88.

6. Hirsch U. Der Waldrapp (Geronticus eremita), ein Beitragzur Situation in seinemostlichenVerbreitungsgebiet. Vogelwelt. 1980;101:219-236.

7. Kasparek M. Die Vögel der Türkei. EineÜbersicht. Heidelberg: Max KasparekVerlag; 1992.

8. Fellous A. Last data on the Northern Bald Ibis (Geronticus eremita) in Algeria. In: Proceedings of the International Advisory Group for the Northern Bald ibis IAGNBI's Conservation and Reintroduction workshop. Spain: Vejer; 2006.

9. Serra G. Discovery of Northern Bald Ibises in Syria.World Birdwatch BirdLife International Magazine. 2003;25:10-13.

10. Serra G, Abdallah M, Abdallah A, et al. Discovery of a relict breeding colony of Northern Bald Ibis (Geronticus eremita) in Syria: still in time to save the eastern population? Oryx. 2004;38(1):1-7.

11. López JM, Quevedo MA, Sánchez Í, et al. Crónica de la reintroducción del ibis eremita en Andalucía. Quercus. 2015;349:14-23.

12. Muñoz AR, Ramírez J. Reintroduced northern Bald ibises from Spain reach Morocco. Oryx. 2017;51(2):203-207. 
13. Bowden C. Last chance for the Northern Bald ibis. World Birdwatch 1998;20:12-16.

14. Bowden C, Smith KW, El bekkay M, et al. Contribution of research to conservation action for the Northern Bald ibis (Geronticus eremita) in Morocco. Bird Cons Inter. 2008;18:74-90.

15. Oubrou W, El Bekkay M. Rapport sur la reproduction 2016 de la population des Ibis chauves dans la région de Souss-Massa. Report of the 2016 Northern Bald ibis breeding season at Souss-Massa NP, Morocco; 2016
16. Rencurel P. L'Ibis chauve (Geronticus eremita) dans le Moyen Atlas. Alauda. 1974;42:143-158.

17. Fox H, Moore $\mathrm{H}$. An investigation into the stability of Bald Ibis nest sites on the coast of Southern Morocco. Report to RSPB and Centre for Land Evaluation and Management. UK: University of Derby; 1998. 